\title{
KEDUDUKAN MORAL DAN HUKUM DALAM BANGUNAN HUKUM INDONESIA
}

\author{
Oleh: \\ Taufik Firmanto \\ Mahasiswa Program Doktor Ilmu Hukum Universitas Brawijaya
}

\begin{abstract}
:
Discoursing between law and morality is an interesting conversation among a legal scholars and jurists. Observing of legal developments are reviewed historically, the morality of jurisprudence from time to time undergoes sharp reductions. In the early stages of modern human civilization, the morality of jurisprudence still stands firmly on the foundation of the religion (christian). Moral judgments about good or bad, right or wrong, are consistently restored to the divine rules. Faced with the power of the church and the kings, came the antithesis of contradictory extreme thought, the idea that denied the existence of God or rejected the hegemony of religion and the church. The opposing of two rivals in concepts, theories and practices are concerning of the moral role of life. In turn, it had a significant influence on the development of jurisprudence in Europe at the time, leading to the spread of colonization in the eastern hemisphere.
\end{abstract}

\section{Keywords: Moral, Law, Indonesian Law.}

\section{Pendahuluan}

Secara kodrati, manusia adalah mahkluq sosial yang secara alamiah pula membutuhkan kehadiran pribadi-pribadi lain dalam menjalankan aktifitas serta menjaga eksistensinya. Dalam bahasa yang lebih sederhana, manusia membutuhkan manusia lain dalam usahanya mencapai tujuan pribadinya. Atas dasar itulah manusia selalu ingin hidup bermasyarakat atau berkelompok, hal inilah yang juga menunjukkan kepada kita bahwa manusia menurut kodratnya tidak dapat melepaskan diri dari manusia lainnya. Kehidupan sosial manusia adalah sebuah kehidupan yang kompleks. Dalam kesehariannya manusia sebagai bagian dari masyarakat tak dapat dipisahkan dengan nilai, moral dan hukum.

Nilai-nilai (value) menjadi landasan sangat penting yang mengatur semua perilaku manusia. Nilai menjadi sumber kekuatan dalam menegakkan suatu ketertiban dan keteraturan sosial. Peran moral sebagai benteng perilaku etik, sedangkan kekuatan hukum 
menjadi kontrol dalam mengatur keadilan akan hak dan kewajiban setiap manusia dalam menjalankan peran-peran penting bagi kehidupan manusia. Dengan demikian peran nilai, moral maupun hukum menjadi bagian penting bagi proses pembentukan karakter suatu bangsa.

Dalam mengatur dan mengurus kebutuhan bersama, agar kehidupan berlangsung secara tertib dan damai seperti inilah, maka muncullah tata aturan, norma atau nilai-nilai yang menjadi kesepakatan universal yang harus ditaati. Semacam hal tersebut di ataslah peradaban manusia dimulai, di mana manusia harus selalu menjunjung tinggi nilai-nilai kemanusiaan. la harus memegangi nilai-nilai aturan yang berlaku mengatur hidup manusia. Nilai-nilai aturan yang mengikat manusia inilah yang kemudian kita kenal sebagai hukum.

Pada dasarnya nilai-nilai yang disebut kaidah hukum itu menetapkan atau bermuatan tuntutan atau keharusan untuk berperilaku dengan cara tertentu dalam situasi kemasyarakatan tertentu. Kepatuhan terhadap nilai-nilai hukum itu tidak sepenuhnya diserahkan pada kemauan bebas dari para warga dan pejabat masyarakat secara perorangan, melainkan dapat dipaksakan dan ditegakkan secara terorganisasi oleh pejabat-pejabat masyarakat yang diberi kewenangan khusus untuk itu, yang pelaksanaannya harus dijalankan sesuai dengan prosedur yang ditetapkan untuk pelaksanaan dan penegakan kaidah-kaidah hukum. ${ }^{1}$

Namun dalam pelaksanannya yang dipengaruhi faktor yang sangat kompleks, di Indonesia, menurut Sodiki, hukum memang susah melepaskan diri dari pengaruh faktor non hukum. Ia mengistilahkan kedudukan hukum lebih sering menjadi hamba poliik, khususnya pada zaman orde lama dan orde baru. Itu artinya, hukum lebih banyak mengabdi kepada elit politik. "Padahal hukum berfungsi memanusiakan manusia, bukan sekadar mencapai tujuan tetapi tujuannya tentang kebahagiaan. Sebab kesejahteraan harus pula dicapai dengan cara-cara yang memuliakan manusia." 2

Dalam kehidupan bernegara, hukum adalah sistem yang terpenting dalam pelaksanaan atas rangkaian kekuasaan kelembagaan. Negara sebagai suatu wilayah yang memiliki suatu sistem atau aturan yang berlaku bagi semua individu di wilayah tersebut, dan berdiri secara berdaulat. Hukum di setiap negara berbeda berdasarkan budaya

1 Sebagian dari kaidah-kaidah hukum itu dirumuskan dalam bentuk aturanaturan hukum tertulis yang dibentuk oleh badan atau pejabat yang memiliki kewenangan untuk itu melalui prosedur untuk pembentukan kaidah hukum, yang keseluruhannya disebut perundang-undangan.

2 Achmad Sodiki dalam talkshow bertema "Menggagas Keadilan Substantif Konstitusional dan Sosialisasi UUD 1945" di auditorium FH UB, Kamis (9/12/2010). Periksa https://prasetya.ub.ac.id/berita/Prof-Achmad-Sodiki-Hukum-yangMemanusiakan-Manusia-1919-id.html 
dan agama masing-masing negara. Hubungan antara negara dan hukum adalah bahwa Hukum bersifat mengikat, negara pun terikat oleh hukum. Negara dalam hal ini pemerintah, membutuhkan hukum untuk mengatur rakyatnya oleh karena itu hukum harus adil dan tidak memihak karena semua orang sama di hadapan hukum.

Hukum positif berupa peraturan perundang-undangan yang berlaku di suatu negara, sepenuhnya mencerminkan apa yang berlaku di tengah-tengah masyarakatnya. Jadi, masyarakatlah yang menentukan hukum. Jika sistem kemasyarakatan suatu bangsa bobrok, maka demikianlah wajah hukumnya. Sebaliknya, jika sistem kemasyarakatannya sehat, maka sehat pula hukumnya. Oleh sebab itu, tidak perlu ada upaya pembentukan hukum yang secara terstruktur dijalankan oleh negara karena hukum tinggal mengikuti apa yang sudah terjadi dan berlaku di masyarakat. ${ }^{3}$

Keberadaan positivisme hukum tidak dapat dilepaskan dari kehadiran negara modern. Sebelum abad ke 18 pikiran itu telah hadir, dan menjadi semakin kuat sejak lahrnya negara modern pada abab ke 18-20 M. Selain itu, pemikiran positivisme hukum adalah bagian yang tidak dapat dilepaskan dari pengaruh perkembangan positivisme (ilmu). Berbeda dengan pemikiran hukum kodrat yang sibuk dengan permasalahan validasi hukum buatan manusia, maka pada positivisme hukum, aktivitasnya justru diturunkan kepada permasalahan konkrit.

Begitu pula dalam pengajaran ilmu hukum, sering terjadi "salah kaprah", yang menempatkan ajaran hukum doktrinal identik dengan filsafat positivisme. Hukum positif diidentikkan sebagai turunan utuh filsafat positivisme. Kajian hukum doktrinal, sesungguhnya sangat erat berhubungan dengan filsafat dan ajaranajaran hukum dari masa ke masa. Bagaimanapun juga, bangsa ini berkepentingan agar perkembangan ilmu hukum dapat berjalan secara wajar, sehat dan mampu menjadi pendorong terwujudnya kehidupan yang lebih adil, bahagia dan sejahtera. Dalam konteks pemikiran demikian, maka keutuhan moral dengan ilmu hukum harus tetap dijaga, baik pada tataran teoretis maupun praktis.

Hikmahanto menyatakan bahwa kurikulum hukum di Indonesia didominasi oleh kepribadian perancang. Dulu ada institusi di lingkungan Departemen Nasional Pendidikan yang memiliki tanggung jawab khusus atas pengembangan sejumlah ilmu pengetahuan, termasuk ilmu hukum. Lembaga ini awalnya diakui sebagai Legal Konsorsium Ilmu Pengetahuan (KIH) yang kemudian diubah menjadi Komisi untuk Disiplin Ilmu Hukum (KDIH). Pada bulan Januari 2003,

3 Durkheim adalah salah satu tokoh utama dari tesis cermin ini. Dalam konstelasi aliran-aliran pemikiran hukum, mazhab sejarah juga termasuk pendukung tesis ini, yakni dengan menyatakan bahwa hukum itu sepenuhnya berasal dari masyarakat. 
KDIH dibubarkan oleh Departemen Pendidikan Nasional. Sejak itu, reformasi kurikulum dan Hal-hal yang berkaitan dengan penyelenggaraan pendidikan hukum telah didesentralisasikan. ${ }^{4}$

Di teori, setiap fakultas hukum untuk saat ini memiliki kebebasan untuk mengubah dan meningkatkan kurikulum yang mereka lihat sesuai. Terlepas dari kebebasan yang nyata ini, Dekan fakultas yang dikelola negara telah berinisiatif untuk bertemu secara berkala dalam sebuah forum yang dikenal sebagai Dekan Dewan Kerjasama Studi Hukum Publik Indonesia (Badan Kerjasama Dekandekan Fakultas Hukum). Keanggotaan Dewan saat ini adalah 34, termasuk Sekolah Hukum Militer Jakarta. ${ }^{5}$

Demikian juga dengan pengaruh-pengaruh hukum alam pada era Skolastik, kemudian pada era Rasionalisme serta pengaruh filsafat positivisme dalam ilmu pengetahuan alam sangat melekat pada kajian hukum doktrinal hingga saat ini. Oleh karena itu bukan hanya filsafat positivisme saja yang mempengaruhi perkembangan kajian hukum doktrinal. Berdasarkan hal itu maka kajian hukum doktrinal sesungguhnya memiliki ciri khas yang berbeda dengan ilmu-ilmu sosial. Apabila ilmu sosial dikembangkan berbasis filsafat positivisme,maka ajaran hukum doktrinal tidak seluruhnya dikembangkan berbasis filsafat positivisme. Tidak semua logika filsafat positivisme bisa diterapkan di dalam hukum doktrinal. ${ }^{6}$

\section{Pembahasan}

Pada mulanya, dalam berbagai literature awal yang memperbincangkan keberadaan hukum (di masa yunani kuno) ditemukan bahwasanya telah terjadi perdebatan yang cukup seru tentang hukum antara kaum filsuf Ionia dengan kaum Sophies. Namun perdebatan mereka tidaklah menemukan perbedaan bahwasanya hukum itu berasal dari suatu kekuatan tak kasat mata, transedental, dan bernuansa religiusitas serta sangat dekat dengan alam semesta (makro kosmos).

Dalam perkembangannya, sebagai bagian dari ilmu sosial yang bersifat dinamis, bidang hukum menunjukkan perubahan yang paradigmatik. Hukum tidak lagi dibangun, dan dijabarkan sesuai dengan tatanan nilai yang bersifat transendental (lex eterna; hukum Tuhan/ kodrati), hukum para nabi dengan risalah kitab suci yang dibawanya (lex devina), atau berasal dari hukum alam (lex natura) seperti pandangan Aquinas semata, tetapi telah bergeser pada pandangan yang

4 Hikmahanto Juwana, "Reformasi Pendidikan Hukum di Indonesia", dalam Asian Journal of Comparative Law Volume 1, Isu 12006 Pasal 8., hal. 5.

5 Ibid, p. 9

6 FX. Adji Samekto. 2012. Menggugat Relasi Filsafat Positivisme Dengan Ajaran Hukum Doktrinal. Jurnal Dinamika Hukum Vol. 12 No. 1 Januari 2012. Hlm.74 
melihat peran manusia begitu dominan dalam merumuskan ketentuan aturan hukum konsep lex humana, yang cenderung bersifat legalistik normatif. Hal ini juga bisa kita temukan pada bangunan hukum Indonesia saat ini. ${ }^{7}$

Hukum senantiasa berkembang sesuai dengan kebutuhan hidup bermasyarakat, berbangsa, dan bernegara. Aspek hukum seperti bidang hukum pidana, hukum perdata, hukum Tata Negara dan sebagainya senantiasa bergerak dan berkembang sesuai dinamika zamannya. Dalam bentuk paling sederhana, hukum dapat dirasakan dan diwujudkan yaitu peraturan perundang-undangan. Dalam bentuk lebih rumit, wujud hukum tersebut dikendalikan oleh sejumlah asas, doktrin, teori, atau filosofi hukum yang diakui oleh sistem hukum secara universal.

Dalam hal ini, Ilmu hukum dapat dikaji dalam dua perspektif. Pertama, ilmu hukum yang mengkonsep-sikan hukum sebagai ajaran, norma yang me-ngandung nilai-nilai (values). Kajiannya bersifat normatif yang berciri law as what in the writ-ten atau law as what in the books. Ilmu hukum dalam kajian yang bersifat normatif atau doktrinal ini memuat keharusan-keharusan (what ought to be), jadi bersifat das sollen. Di dalam kajian perspektif normatif (doktrinal) termasuk pula kajian filosofis yang sifatnya apriori, yang artinya tidak mendasarkan pada bukti-bukti dulu tetapi pada ajaran-ajaran, nilai-nilai yang sifatnya abstrak.

Kajian-kajian yang bersifat yuridis-filosofis mempelajari dasar-dasar yang bersifat meta-yuridis terutama mempelajari nilai-nilai, ajaran-ajaran yang melahirkan suatu norma. Misalnya pengkajian tentang latar belakang mengapa muncul ajaran tentang fiksi hukum. Ajaran fiksi hukum menyangkut nilai-nilai tentang hubungan individu masyarakat dan kekuasaan. Kajian ini tentu harus menelusuri nilainilai, ajaran-ajaran dari filosof-filosof besar masa yang lalu. ${ }^{8}$

Abad ke-19 menandai munculnya gerakan positivisme dalam ilmu hukum dan abad tersebut menerima warisan pemikiran-pemikiran dari masa-masa sebelumnya yang bersifat idealistis. Perkembangan dan perubahan dalam masyarakat yang terjadi dalam abad ke-

7 Lihat Thomas Aquinas (1225 - 7 Maret 1274), karyanya yang paling dikenal adalah Summa Theologiae, dan dan Summa contra Gentiles. Selama masa jabatannya di Paris, ia merampungkan bagian kedua Summa Theologiae serta menulis De virtutibus dan De aeternitate mundi, contra murmurantes (Tentang Keabadian Dunia Ini, melawan Para Penggerutu), karya yang disebutkan terakhir membahas paham kontroversial Averrois dan Aristotelian mengenai tiada berawalnya dunia ini. Sayangnya, Summa Theologiae tetap tidak terselesaikan hingga akhir hidupnya.

8 Bandingkan FX. Adji Samekto, 2012. Menggugat Relasi Filsafat Positivisme Dengan Ajaran Hukum Doktrinal. Jurnal Dinamika Hukum Vol. 12 No. 1 Januari 2012. 
sembilanbelas menimbulkan semangat serta sikap yang bersifat kritis terhadap masalah-masalah yang dihadapi.

Filsafat modern yang dikenal dan sangat memengaruhi paradigma berpikir Barat adalah Positivisme Logis. Paham ini tidak mengakui metafisika. Mereka hanya mengakui persepsi panca indera sebagai satu-satunya yang "ada". Kalangan ilmuan Barat mengakui bahwa dengan adanya filsafat Positivisme Logis, Barat sukses mencapai hasil yang gemilang dalam perkembangan ilmu pengetahuan.

\section{Positivisme Hukum.}

Di awal abad ke 19 berkembang "positivism". Aliran ini mejalar kesemua cabang ilmu sosial termasuk ilmu hukum. Kaum positivis menganggap bahwa yang sebenarnya dinamakan hukum hanyalah norma norma yang telah ditetapkan oleh negara. Pada waktu itu, sebagai akibat dari kemajuan-kemajuan dalam bidang industri perdagangan, transportasi, terjadilah kekosongan besar dalam perdagangan. Berhadapan dengan kekosongan tersebut, hukum memberikan respon yang sangat massif dan melahirkan suatu orde baru tatanan hukum yang tidak ada bandingannya, bukan hanya sampai waktu itu, tetapi juga sampai sekarang.

Lahirlah perundang-undangan baru, bidang hukum baru, system dan pengorganisasian baru yang berpuncak pada kodifikasi. Sehubungan dengan itu, kita menyaksikan bagaimana ilmu hukum disibukkan oleh penggunaan metode baru yang mempertajam pengkajian terhadap hukum peraturan perundangan. Perkembangan yang demikian mendorong ilmu hukum dan metode hukum untuk memusat dan berkonsentrasi kepada misi menjaga atau mempertahankan tatanan hukum perundangan baru yang tengah menanjak itu. Metode-metode menjadi sangat normative, positivistik, dan legalistic.

Bisa dicermati, bahwa The state of the art dalam ilmu hukum pada abad ke-19 adalah positivistik. Positivisme menjadi aliran yang dominan. Contoh sangat mencolok adalah Reine Rechtslehre dari Hans Kelsen. Menurut Kelsen, hukum adalah susunan logis dari peraturanperaturan yang berlaku pada satu tempat tertentu. Fokus perhatian hukum semata-mata pada bentuk, bukan pada isi, sehingga hukum tetaplah sah walaupun tidak adil dan tidak megandung nilai-nilai moralitas. Tokoh-tokoh teoretisi positivisme lain, seperti John Austin dan Hart, mereka menjadikan tugas ilmiahnya sebagai pemberi legitimasi terhadap hukum positif, dan mencoba membangun suatu teori mendasar, dimulai dari hakikat peraturan hukum dan 
membedakan serta memisahkannya dengan moral, etika, kesusilaan, agama maupun norma-norma kehidupan lain. ${ }^{9}$

Hal lain yang turut menyuburkan paham ini adalah tuntutan konsep Negara modern yang mewajibkan adanya ketertiban hukum dalam bernegara. Jean Jasque Rousseau (1712-1778) mendalilkan bahwa Negara hasil suatu perjanjian bermasyarakat yang disebut staat, state (status hukum atau status bernegara) maka analisis dalam persoalan kenegaraan berkisar pada hukum yaitu membentuk hukum (legislatif), melayani dan melaksanakan hukum (eksekutif), dan penegakan hukum (yudikatif). Ide ini juga menemukan landasan teoritisnya pada teori pembagian kekuasaannya Montesquieu yang mengintroduksir ide Trias Politica di bidang ketatanegaraan.

Dengan demikian, hukum sepenuhnya dipisahkan dari keadilan dan didasarkan atas gagasan-gagasan tentang yang baik dan buruk serta didasarkan pula atas kekuasaan yang lebih tinggi. Hukum menurut Austin, dibagi dalam hukum yang diadakan oleh Tuhan untuk manusia (hukum Tuhan), dan undang-undang yang diadakan oleh manusia untuk manusia (hukum manusia). Setiap hukum positif dihasilkan dari pembentuk hukum, yang ditentukan secara tegas dan semua hukum positif dibentuk oleh yang berkuasa atau badan yang berwenang untuk itu. Teori model positivistik Austin inilah yang dipandang Satjipto Rahardjo, sebagai produk hukum yang final, artinya, konsep hukum sebagai produk final lazim bergandengan dengan pemahaman hukum sebagai perintah atau komando.

Aliran hukum positif berangkat dari pandangan bahwa hukum tidak berasal dari Tuhan atau alam, melainkan dari manusia sendiri berdasarkan kemampuannya untuk merumuskan ketentuan hukum yang sumbernya dapat saja digali dari nilai-nilai yang berkembang di masyarakat. Hukum lahir untuk mengikat masyarakat karena adanya perjanjian sosial (social contract), manusia sendirilah yang memang menghendaki. Aliran hukum positif memandang perlu untuk memisahkan secara tegas antara hukum dan moral. Dalam kacamata positivis, tiada hukum kecuali perintah penguasa, bahkan aliran positivitas legalisme menganggap bahwa hukum identik dengan undang-undang.

Dalam perspektif positivisme yuridis, hukum dipandang sebagai suatu gejala tersendiri yang perlu diolah secara ilmiah. Tujuan postivisme yuridis adalah pembentukan struktur-struktur rasional system-sistem yuridis yang berlaku. Dalam praksisnya konsep ini menurunkan suatu teori bahwa pembentukan hukum bersifat

9 Untuk menafsirkan hukum tidak perlu bimbingan norma sosial, politik dan moral melainkan cukup disimpulkan dari undang-undang. Tokohnya adalah: R. von Jhering dan John Austin (analytical jurisprudence), atau Hans Kelsen yang terkenal dengan ajaran Teori Hukum Murninya. 
professional yaitu hukum merupakan ciptaan para ahli hukum. Prinsipprinsip positivisme yuridis adalah:

1. Hukum adalah sama dengan undang-undang; hal ini didasarkan pemikiran bahwa hukum muncul berkaitan dengan Negara, sehingga hukum yang benar adalah hukum yang berlaku dalam suatu Negara;

2. Tidak ada hubungan mutlak antara hukum dan moral; hukum adalah ciptaan para ahli hukum belaka;

3. Hukum adalah suatu closed logical system.

Hegemoni aliran positivistime-sekular seakan telah menjadi panggilan sejarah sekaligus bagian dari proses perkembangan ilmu hukum di sebagian besar belahan dunia ini. Hukum modern sebagai bentuk matang dari positivisme, menjadi kehilangan ciri kemanusiaannya yang utuh, ketika akal (ratio) diperankan melampaui batas-batas yang proporsional dengan mengabaikan wilayah-wilayah yang paling substansial, yaitu qalbu. Sebagaimana dinyatakan oleh Nasr (1976) hukum modern hanya mampu mengantarkan manusia untuk menemukan setengahnya saja dari dunia dan tidak bisa membantu manusia untuk menemukan The Great Chain Being. Pemositifan hukum dalam perundang-undangan menjadikan hukum itu terbatas dan sering tertinggal oleh dinamika perubahan masyarakat. Untuk itu, diperlukan cara-cara yang dapat menjadi sistem hukum positif itu survive dan tetap mampu menyelesaikan persoalan yang dihadapkan kepadanya, Konstruksi hukum, penafsiran analogi, penghalusan hukum, adalah contoh-contoh untuk itu

Dalam perspektif ke-Indonesiaan, penjajahan oleh barat selama lebih dari 300 tahun adalah pihak yang paling gampang dituding sebagai kambing hitam yang menyisakan wajah hukum Indonesia seperti saat ini. Dalam tata hukum hindia belanda, peminggiran hukum adat Indonesia misalnya bisa kita temukan pada pasal 15 "Algemene bepalingen van wetgeving voor Indonesie" (Peraturan Umum mengenai Perundang-undangan untuk Indonesia) yang mengatakan, "... adat kebisaaan tidak merupakan hukum, kecuali apabila undang-undang menyatakan itu".

Hal ini sekaligus secara legal formil menafikkan hukum adat Indonesia yang notabene dipengaruhi oleh kearifan budaya lokal yang berakar pada kepercayaan terhadap Tuhan Yang Maha Esa, penghormatan terhadap ajaran para nabi, serta kehidupan yang senantiasa bersahabat dengan alam. Menurut Satjipto Rahardjo (2010: $\mathrm{x})$, suatu perilaku hukum baru mesti dibangun dan dikembangkan untuk mendukung perubahan status dari jajahan ke kemerdekaan, akan tetapi tampaknya tidak mudah merubah perilaku bangsa yang dijajah menjadi bangsa yang merdeka ke arah yang sempurna.

\section{Hukum dan Moral}


Kajian Hukum dan moral mempunyai kaitan erat di antara keduanya, meskipun hukum tidaklah sama dengan moralitas begitu juga sebaliknya. Hukum mengikat kepada semua orang sebagai warga Negara, sedangkan moral hanya mengikat orang sebagai individu. Dalam teori pemisahan antara hukum dan moral bahwa hukum adalah suatu hal dan moralitas adalah hal lain. Artinya bahwa hukum dan moralitas tidaklah sama meski mempunyai hubungan erat diantara keduanya dan juga bukan tidak bisa dipisahkan hubungan antara hukum dan moral. Namun ini bukan berarti bahwa para penegak hukum seperti polisi, jaksa, dan hakim hanya memberikan perhatian terhadap hukum dan tidak memberikan perhatian terhadap moralitas. Sebenarnya hukum yang baik berasal dari moralitas yang baik, dan moralitas yang baik melahirkan hukum yang baik pula (Ka'bah, 2004:144).

Adjie Samekto, dengan mengutip Herman J. Pietersen, menyatakan bahwa Hukum (yang diterjemahkan dari kata "law" dalam bahasa Inggris) adalah suatu bangunan normatif. Dalam pengertian ini hukum dikonsepsikan se- bagai an instrument of the state or polis con cerned with justice, with rules of conduct to regulate human behaviour. Jadi menurut pandangan ini hukum merupakan instrumen untuk menegakkan keadilan yang wujudnya berupa pedoman perilaku dengan fungsi utamanya mengatur perilaku manusia. Inilah basis berpikir ajaran hukum doktrinal. ${ }^{10}$

Antara kaidah hukum dan moral memiliki sumber yang berbeda. Kaidah Moral bersumber dari dalam diri individu manusia yang kebenarannya diakui secara universal. Moral berhubungan dengan manusia sebagai individu sedangkan hukum (kebiasaan, sopan santun) berhubungan dengan manusia sebagai makluk sosial. Sementara kita tahu bersama bahwa hukum beesumber dari lemabaga berwenang yaitu negara. Kemudian mucul pertanyaan mengapa harus universal/ objektif dan tidak bergantung dari hati nurani saja?

Mencermati Perkembangan ilmu hukum ditinjau secara historis, moralitas ilmu hukum dari waktu ke waktu mengalami pereduksian secara tajam. Pada tahap-tahap awal peradaban manusia, moralitas ilmu hukum masih berdiri kokoh di atas fondasi agama. Penilaian moral mengenai baik/buruk, benar/salah, secara konsisten dikembalikan pada aturan-aturan yang bersifat Illahiah. ${ }^{11}$

${ }^{10}$ FX. Adji Samekto. 2012. Menggugat Relasi Filsafat Positivisme Dengan Ajaran Hukum Doktrinal. Jurnal Dinamika Hukum Vol. 12 No. 1 Januari 2012. Hlm. 74.

11 Secara sosio-historis, pemikiran tokoh-tokoh gereja dan raja-raja di Eropa sepanjang Abad Pertengahan (abad V-XV M) telah mengharuskan segala urusan kehidupan tunduk menurut ketentuan hukum agama. Mulai dari urusan keluarga, hukum, ekonomi, politik, sosial, seni sampai dengan teologi dan sains, keseluruhannya harus mengikuti ketentuan apa yang dituntunkan gereja. 
Moral religius merupakan moral kehidupan. Ada semacam konsesnsus bahwa seluruh aspek kehidupan tidak ada yang bebas, lepas dan netral dari nilai-nilai kebenaran dan keadilan, maka sebenarnya apa yang disebut moral menjadi identik dengan moral ilmu hukum. Jangkauan dan cakupan moral menjadi sangat luas, menyeluruh dan menyentuh semua sendi-sendi kehidupan bagi siapapun, di manapun dan kapanpun. Dengan kata lain, moral atau moral ilmu hukum bersifat universal. Penilaian moral menjadi tidak berbeda dengan politisasi moral. Perkembangan semakin memprihatinkan ketika penilaian moral sangat dipengaruhi oleh wacana ekonomi politik. Penilaian moral mengenai baik/buruk, benar/salah, moral/amoral sangat dilandasi oleh kepentingankepentingan ekonomi (khususnya kapitalisme).

Namun, pada perkembangan selanjutnya moralitas religius itu telah tereduksi oleh kepentingan-kepentingan politik dan kekuasaan. Penilaian moral diatur oleh konvensi atau kode-kode yang dibuat berdasarkan akal manusia sendiri, dan semuanya tidak dapat dilepaskan dari kaitan-kaitan politiknya. Sebagai suatu tatanan yang dinamis dan senantiasa berkembang sesuai kodrat alam, pemikiran serta keyakinan akan kekuasaan hukum Tuhan pun mulai digugat.

Berhadapan dengan kekuasaan gereja dan raja-raja tersebut, muncullah antitesis berupa pemikiran ekstrem yang kontradiktif, yaitu pemikiran yang mengingkari keberadaan Tuhan atau menolak hegemoni agama dan gereja. Perseteruan dua kubu yang berseberangan dalam konsep, teori maupun praktik-praktik mengenai peran agama dalam perikehidupan, pada gilirannya berpengaruh cukup signifikan pada perkembangan ilmu hukum di Eropa pada saat itu.

Dalam khasanah perbincangan perihal persinggungan antara hukum dengan moralitas tentu tak dapat mengeyampingkan nama Hart. Buku yang berhasil membawa nama Hart berkibar di jajaran para teoretikus hukum mutakhir adalah The Concept of Law. ${ }^{12}$ Melalui buku tersebut Hart mengangkat tiga pertanyaan penting dalam filsafat hukum, yakni -Bagaimana hukum berbeda dari dan bagaimana ia terkait dengan perintah yang ditopang oleh ancaman? Bagaimana kewajiban hukum berbeda dari, dan bagaimana ia terkait dengan kewajiban moral? Apa itu peraturan dan sampai sejauh mana hukum merupakan persoalan mengenai peraturan. Dalam pandangan Hart, The Concept of Law bertujuan meningkatkan pemahaman mengenai hukum (law), paksaan (coercion) dan moralitas (morality) sebagai hal yang berbeda namun terkait dengan gejala sosial.

Konsep moralitas H.L.A Hart dalam paradigma rasional berpegang pada "kredo" moralitas harus menjadi syarat minuman

12 Lihat HLA Hart. 2011. Konsep Hukum (The Concept Of Law). Alih bahasa: Lhozim. Bandung: Nusa Media. 
dari hukum. Hal ini disebabkan karena dua faktor: a) Manusia memiliki keterbatasan berbuat baik pada orang lain: dan b) Hukum memiliki keterbatasan dalam mengatur perkembangan masyarakat. Sedangkan konsep moral meyakini jika manusia secara spesifik memiliki perasaan tanggung jawab dan rasa malu akan perbuatan buruk yang ada pada dirinya yang tidak mungkin dapat dihindari. Hal ini membuktikan keniscayaan keberadaan Tuhan sebagai sumber pemberi tanggung jawab. ${ }^{13}$

Hart merupakan pemikir hukum penting abad ke-20. Karyakarya Hart, seperti diungkapkan seorang pemikir hukum terkemuka sekaligus kerabat dekatnya, Tony Honoré, merupakan karya yang paling banyak dibaca dan akan terus-menerus menjadi fokus diskusi. Hart mengklaim dirinya sudah menjawab tiga pertanyaan penting tersebut dan karena itu ia telah memecahkan teka-teki yang ada dalam filsafat hukum. Selanjutnya Hart mengemukakan bahwa hukum dan moral harus mempunyai isi minimum tertentu yang terefleksi dalam suatu norma dan sanksi hukum.

Selain itu, ia juga berpendapat bahwa "rule of recognition"14 lebih penting daripada peraturan-peraturan dasar konstitusional yang lain. Eksistensi norma dalam aspek internal dari Hart, harus melibatkan unsur kehendak seseorang yang berperilaku sesuai dengan pola yang dianggap baik. Ia berpendapat bahwa sistem hukum ada hanya jika dilaksanakan secara efektif atau hampir seluruh penduduk mematuhinya, baik secara pasif maupun terpaksa.

Lebih lanjut, Hart mengemukakan bahwa eksistensi sistem hukum dapat diterima apabila keberlakuan dan "Rule of Recognition" dipatuhi oleh sebagian besan warga masyarakat. Hart berpendapat bahwa penerimaan segala peraturan konstitusi yang meliputi "Rule of Recognition", perubahannya, peraturan-peraturan yang memecahkan konflik dan penegakannya, merupakan dasar dari tertib hukum. ${ }^{15}$

Moralitas mengajarkan bahwa manusia tidak boleh bertindak yang bertentangan dengan hati nurani, karena itu harus diikuti meski secara objektif ia sesat. Akan tetapi manusia wajib juga mengembangkan hati nurani dan seluruh kepribadian etisnya sampai menjadi matang dan seimbang, pada akhirnya orang yang sungguhsungguh dewasa dalam bidang etis, putusan subjektif dari hati nuraniakan sesuai dengan kualitas objektif dari perbuatannya. Hati nurani sangatlah penting karena itu akan menjadi tembok pertahanan

13 HLA Hart, ibid.

14 Rules of Recognition (asas pengakuan), merupakan suatu kriteria identifikasi hukum mana yang dianggap sah dan untuk sistem hukum mana aturan tersebut berlaku, Rules of Adjudication, siapa yang berhak memaksakan aturan tersebut dan ketentuan tersebut untuk sistem hukum yang mana, Rules of Change, siapa dan bagaimana mekanisme perubahan/ penghapusan aturan hukum tersebut.

15 HLA Hart, ibid. 
terakhir tindakan manusia. Akan tetapi hati nurani haruslah dibina hingga menuju sebuah kedewasaan etis demi terwujudnya sebuah pernyataan objektif menurut kebenaran universal.

Akhirnya, perbincangan ini harus menjawab pada satu pertanyaan subtansif: Bagaimana Seharusnya Hukum di Negara Ini Bekerja..!!?? Penegakan hukum merupakan pusat dari seluruh "aktivitas kehidupan" hukum yang dimulai dari perencanaan hukum, pembentukan hukum, penegakan hukum dan evaluasi hukum. Penegakan hukum pada hakikatnya merupakan interaksi antara berbagai perilaku manusia yang mewakili kepentingan-kepentingan yang berbeda dalam bingkai aturan yang telah disepakati bersama. Oleh karena itu, penegakan hukum tidak dapat semata-mata dianggap sebagai proses menerapkan hukum sebagaimana pendapat kaum legalistik.

Mengapa penegakan hukum di Indonesia tercerabut dari akar moralitas, sebenarnya salah satu faktor sumbangan terbesar adalah karena kita menyamakan hukum sama dengan teks peraturan perundang-undangan, sedangkan jika kita eksplorasi lebih dalam materi muatan peraturan perundang-undangan yang dirancang oleh negara melalui lembaga yang diberikan kewenangan tidaklah bebas dari kepentingan-kepentingan politik dalam berbagai dimensinya, sehingga publik tidak bisa berharap banyak kepada peraturan perundang-undangan atau hukum tertulis, sebagai satu-satu pintu masuk pemahaman ilmu hukum tata negara, khususnya di Indonesia.

Namun proses penegakan hukum mempunyai dimensi yang lebih luas daripada pendapat tersebut, karena dalam penegakan hukum akan melibatkan dimensi perilaku manusia. Dengan pemahaman tersebut maka kita dapat mengetahui bahwa problem-problem hukum yang akan selalu menonjol adalah problema "law in action" bukan pada "law in the books". ${ }^{16}$

Dalam bangunan hukum Indonesia saat ini, kita bisa dengan mudah menemukan produk hukum warisan colonial yang bersifat Positivistik dan legalistic. Ini tentunya perlu menjadi kajian serius bagi kita untuk menghadirkan produk hukum yang sesuai dengan nafas hidup dan falsafah bangsa serta mengakomodir kebutuhan hukum bangsa ini. Ini menjadi penting kita lakukan karena telah kita sepakati bahwa hukum yang berkiblat pada filsafat positivisme dianggap memberikan sumbangsih pada kemerosotan pada bangsa ini.

Tidak berdayanya rejim hukum positif untuk menyelesaikan masalah-masalah sosial kala itu ditengarai disebabkan oleh 2 faktor, yakni: Pertama, bangunan sistem hukum beserta doktrin-doktrin yang menopangnya memang tidak memungkinkan hukum melakukan

16 Modeong Supardan., Fakrulloh, Zudan Arif. 2005. Legal Drafting Berporos Hukum Humanis Partisipatoris. Jakarta. Penerbit Perca. 
perubahan sosial atau menghadirkan keadilan substantif. Kondisi ini disebabkan oleh faktor Kedua yakni tercemarnya institusi-institusi hukum karena bekerja sebagai alat kekuasaan sehingga menyebabkan sulitnya menghadirkan tertib hukum seperti yang dijanjikan oleh penganjur positivisme hukum. Situasi-situasi tersebut dianggap tidak terlepas dari watak dogmatika hukum (legal dogmatics) yang menjauhkan diri dari sentuhan aspek-aspek etika, moral dan keadilan sosial.

Hukum adalah sarana untuk menciptakan ketertiban dan kesejahteraan. Dalam bahasa bijak orang tua kita, hukum haruslah mencerminkan keadaan tata tenterem karta raharja. Tata-tenterem dapat dikatakan menghukumkan apa yang dianggap baik oleh masyarakat kita; karta-raharja, mengindikasikan suatu perencanaan, perekayasaan, atau perakitan masyarakat yang kita cita-citakan. Sudah seharusnya bangsa yang besar ini menemukan bentuk hukumnya sendiri. Hal ini bisa kita lakukan dengan menggali dari dalam dasar hukum kita, suatu konsep hukum dengan perspektif intregalistik Indonesia yaitu Pancasila sebagai falsafah bangsa.

Hukum seyogyanya menjadi petunjuk hidup, dengan bahasa yang sederhana kita katakan bahwa keberadaan hukum adalah sebagai alat bagi manusia untuk mencapai kesejahteraanya. Hukum tidak dipahami sebagai suatu institusi yang esoteric dan otonom, melainkan sebagai bagian dari proses social yang lebih besar, sehingga dengan tegas Satjipto Rahardjo menyatakan bahwa: "law as a great Anthropological Document", artinya pemahaman yang memahami hukum sebagai sekumpulan aturan-aturan guna kepentingan profesi sebagaimana pemahaman kaum positivistik harus dirubah dengan penahaman bahwa hukum adalah dokumen antropologis. ${ }^{17}$

\section{Simpulan}

Moral mengajarkan mana yang baik dan mana yang buruk menurut kebenaran umum tanpa adanya sebuah aturan yang jelas mengenai sanksi. Sementara, lebih konkret daripada itu, hukum mengatur larangan dan keharusan dengan aturan sanksi yang jelas yang dibuat oleh negara, keberadaan hukum sangat dipengaruhi oleh rasionalitas manusia. Moral religius merupakan moral kehidupan. Apabila kita sepakat bahwa seluruh aspek kehidupan tidak ada yang bebas, lepas dan netral dari nilai-nilai kebenaran dan keadilan, maka sebenarnya apa yang disebut moral religius menjadi identik dengan moral ilmu hukum.

Jangkauan dan cakupan moral religius menjadi sangat luas, menyeluruh dan menyentuh semua sendi-sendi kehidupan bagi

17 Lihat Rahardjo, Satjipto. 2007. Biarkan Hukum Mengalir; Catatan kritis tentang pergulatan manusia dan hukum. Jakarta: Penerbit Buku Kompas. 
siapapun, di manapun dan kapanpun. Dengan kata lain, moral religius atau moral ilmu hukum bersifat universal. Penilaian moral menjadi tidak berbeda dengan politisasi moral. Perkembangan semakin memprihatinkan ketika penilaian moral sangat dipengaruhi oleh wacana ekonomi politik. Penilaian moral mengenai baik/buruk, benar/salah, moral/amoral sangat dilandasi oleh kepentingankepentingan ekonomi (khususnya kapitalisme). Dengan perkataan lain, nilai-nilai moral itu kini menjadi bagian integral dari nilai-nilai komoditi saja.

Jika mencermati rumusan etika moral Pancasila oleh Notonagoro (1984), yang sekaligus akan memperjelas benang merahnya dengan pembahasan awal kita tentang hukum sejak jaman yunani kuno hingga mazhab posivisitic. Hakikat manusia Indonesia ialah untuk memiliki sifat dan keadaan yang berperi Ketuhanan Yang Maha Esa. Hakikat manusia Indonesia ialah untuk memiliki sifat dan keadaan yang berperi kemanusiaan, peri keadilan dan peri keadaban. Hakikat manusia Indonesia ialah untuk memiliki sifat dan keadaan yang berperi kesatuan dan peri kebangsaan. Hakikat manusia Indonesia ialah untuk memiliki sifat dan keadaan yang berperi kebijaksnaan dalam permusyawaratan/perwakilan. Hakikat manusia Indonesia ialah untuk memiliki sifat dan keadaan yang berperi keadilan sosial bagi seluruh rakyat Indonesia. ${ }^{18}$

Hakekatnya, ilmu hukum dalam keotentikannya merupakan ilmu yang sarat dengan moral dan moralitas. Ilmu hukum merupakan realitas kodrati yang eksis dan tertanamkan di setiap hati nurani manusia dan a priori terhadap segala bentuk perilaku manusia. Dalam posisinya sebagai norma kehidupan seperti itu, maka ilmu hukum merupakan ilmu amaliah. Artinya, tidak ada ilmu hukum tanpa diamalkan, dan tidak ada sesuatu amalan digolongkan bermoral kecuali atas dasar ilmu. Berhadapan dengan kecenderungan adanya pemisahan antara moral dan moralitas dengan ilmu hukum, menjadi relevan untuk dikaji, diungkap dan diangkat kembali urgensi reintegrasi moral ke dalam ilmu hukum.

Hukum dasar kita menegaskan bahwa pembinaan hukum kita haruslah bersemangat kekeluargaan (gotong royong), dan bukanlah bersifat individualistik. Hukum tidak boleh hanya mengedepankan aspek kepastian hukum yang legalistic formiil belaka, namun juga harus mengakomodir aspek keadilan dan kemanfaatan hukum dengan memerhatikan nilai-nilai etika dan moral yang tumbuh dalam masyarakat. Etika berasal dari bahasa yunani ethos, sedangkan moral berasal dari bahasa latin mores. Keduanya memiliki pengertian the customs or way of life.

18 Notonagoro. 1984 . Pancasila Secara Ilmiah Populer,cetakan keenam. Bina Aksara, Jakarta. 


\section{Daftar Pustaka}

Ansori, Abdul Ghofur. 2006. Filsafat Hukum Sejarah, Aliran dan Pemaknaan. Yogyakarta: Gadjah Mada University Press.

Dimyati, Khuzaifah. 2010. Teorisasi Hukum, Studi tentang Pemikiran Hukum di Indonesia 1945-1990. , Yogyakarta: Genta Publishing.

Fauzi, Ahmad. 2003. Pancasila (Tujuan Dari Konteks Sejarah, Filsafat, Ideologi Nasional Dan Ketatanegaraan Republik Indonesia): Malang: PT. Danar Wijaya Univesitas Brawijaya.

Hart, HLA. 2011. Konsep Hukum (The Concept Of Law). Alih bahasa: Chozim. Bandung: Nusa Media.

Kaelan, 2004. Pendidikan Pancasila. Yogyakarta: Paradigma.

Modeong Supardan., Fakrulloh, Zudan Arif. 2005. Legal Drafting Berporos Hukum Humanis Partisipatoris. Jakarta. Penerbit Perca

Notonagoro. 1984 . Pancasila Secara Ilmiah Populer. cetakan keenam. Jakarta. Bina Aksara.

Rahardjo, Satjipto. 2007. Biarkan Hukum Mengalir; Catatan kritis tentang pergulatan manusia dan hukum. Jakarta: Penerbit Buku Kompas.

Rahardjo, Satjipto. 2010. Sosiologi Hukum; Perkembangan Metode dan Pilihan Masalah. , Yogyakarta: Genta Publishing.

Ridwan, Juniarso \& Achmad Sodik. 2010. Tokoh-tokoh Ahli Pikir Negara E Hukum dari Zaman Yunani Kuno sampai Abad ke-20. , Bandung: Penerbit Nuansa.

Santoso, D. 2013. Materi Ajar Mata Kuliah Pendidikan Pancasila. Jakarta: Direktorat Jendral Pendidikan Tinggi Dapertemen Pendidikan Nasional. Kementrian Pendidikan dan kebudayaan Republik Indonesia.

Susanto, Anthon F. 2010. Dekonstruksi Hukum, Eksplorasi Teks dan Model Pembacaan. Yogyakarta: Genta Publishing.

Tanya, Bernard L. 2010. Teori Hukum, Startegi Tertib Manusia Lintas Ruang dan Generasi, , Yogyakarta: Genta Publishing.

Hikmahanto Juwana, Reformasi Pendidikan Hukum di Indonesia. dalam Asian Journal of Comparative Law, Volume 1, Isu 12006.

Samekto, FX. Adji. 2012. Menggugat Relasi Filsafat Positivisme Dengan Ajaran Hukum Doktrinal. Jurnal Dinamika Hukum Vol. 12 No. 1 Januari 2012.

Samekto, FX.Adji. Relasi Hukum Dengan Kekuasaan: Melihat Hukum Dalam Perspektif Realitas. Jurnal Dinamika Hukum Vol. 13 No. 1 Januari 2013. 